\title{
Potential chemical defenses of Antarctic benthic organisms against marine bacteria
}

\author{
Oriol Sacristán-Soriano (10), Carlos Angulo-Preckler (10), Jennifer Vázquez ${ }^{\mathrm{b}}$ \& Conxita Avila (1)
}

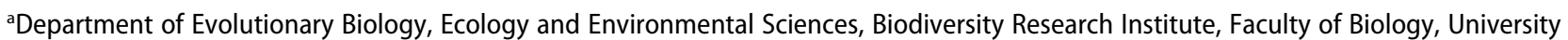

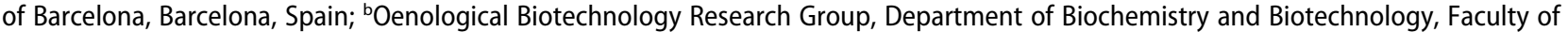
Oenology, University Rovira i Virgili, Tarragona, Spain

\begin{abstract}
The continental shelf of Antarctica harbours rich suspension-feeding macroinvertebrate communities that are continuously exposed to large populations of free-living microbes. To avoid settlement or fouling by undesirable microorganisms that could cause infection or collapse filter-feeding systems, these macroinvertebrates might regulate the epibiotic microbial mat through chemical interactions. In Antarctic chemical ecology, the antibacterial roles of natural products remain mostly unknown. A necessary first step is to identify organisms that produce compounds with potential ecological relevance. For that reason, we tested the crude organic extracts of 116 taxa of Antarctic benthic organisms for antibacterial activity against a panel of seven strains of marine bacteria. Nine out of 11 phyla tested had antibacterial properties. However, inhibitory activity was quite selective and species-specific. These patterns suggest that Antarctic benthic organisms may produce diverse bioactive metabolites with different antibacterial activities or, alternatively, those contrasting profiles may be shaped by environmental and biological interactions acting at a small spatial scale. The reasons of such selectivity remain to be further investigated and may contribute to the identification of bioactive compounds with pharmaceutical applications.
\end{abstract}

\section{KEYWORDS}

Antibacterial activity; natural products; symbiosis; host-symbiont interactions; microbial ecology

\section{Introduction}

Low temperatures and a marked seasonality, with periodic limitations of food resources, characterize Antarctic marine benthic ecosystems. Although perturbations are quite common in shallow areas where ice-scour can be a relevant factor, benthic habitats appear to be quite stable (Gutt 2000). Hence, Antarctic benthic communities are biologically accommodated, mainly structured and regulated by biological interactions (Dayton et al. 1974; Gutt \& Starmans 1998; Arntz et al. 2005) rather than by physical disturbances. The continental shelf of Antarctica houses rich suspension-feeding macroinvertebrate assemblages composed mainly of sponges, soft corals, bryozoans, hydroids and ascidians, as well as abundant macroalgae in the photic zone (Wiencke et al. 2007). Both sessile and sluggish organisms are expected to have developed chemical defensive mechanisms against predators and competitors for space, but also inhibiting settlement and fouling by microorganisms and preventing their overgrowth (e.g., Dayton et al. 1974; Amsler et al. 2000; Peters et al. 2009; Núñez-Pons et al. 2010; Koplovitz et al. 2011; Núñez-Pons et al. 2012; Angulo-Preckler, Cid et al. 2015).

Benthic communities, composed mostly of filterfeeders, are constantly exposed to large populations of free-living microbes (Jenkins et al. 1998), including opportunistic pathogens and fouling microorganisms. However, these marine organisms seem to suffer few obvious microbial infections. Fouling occurs as many benthic organisms host diverse microbial communities on their surfaces (Harder et al. 2003; Thiel et al. 2007; Meyer \& Kuever 2008). This biological interaction can be either advantageous to the host, which may establish a facultative association with certain epibionts and benefit from them, or disadvantageous if it leads to detrimental effects to the host (Wahl 1989). Thus, there might be regulatory mechanisms of the epibiotic microbial mat including a chemical interaction through natural products produced by the host itself or by their associated symbionts with antimicrobial activity against fouling of harmful microorganisms (Walls et al. 1993; Harder et al. 2003; Piel 2004, 2009).

Benthic organisms and their associated microbes are potential sources of biologically active compounds with biotechnological and pharmaceutical uses. Research on drug discovery has focused on the search for potential antimicrobial agents from unexplored areas, such as Antarctica, which is considered a reserve of novel active compounds (Lebar et al. 2007; Avila et al. 2008). Identifying the organisms

CONTACT Oriol Sacristán-Soriano osacriso7@gmail.com EDepartment of Evolutionary Biology, Ecology and Environmental Sciences, Biodiversity Research Institute, Faculty of Biology, University of Barcelona, Av. Diagonal 643, Barcelona, Catalonia 08028, Spain

(4) Supplemental data for this article can be accessed here. 
that produce antimicrobial compounds is a necessary first step towards understanding the antimicrobial roles that these potentially bioactive natural products play in nature. Several bacterial strains have been isolated from diverse Antarctic sources including both marine non-living sources (Figuerola et al. 2014) and benthic invertebrates (Xin et al. 2011; Papaleo et al. 2012; Figuerola et al. 2014). These bacterial strains have the potential to physically interact with the organisms collected for this study, so we can use them to assess whether the Antarctic benthic organisms sampled possess antimicrobial activities against sympatric bacteria.

In the present study, we tested the crude organic extracts of 116 taxa of Antarctic benthic organisms for antibacterial activity against a panel of six strains of Antarctic and one Mediterranean marine bacteria that included isolates from a sponge, a shallow rock, sediment and seawater. We sought to answer the following questions: (1) Do organic extracts tested at natural concentrations inhibit the growth of marine bacteria? (2) Do antibacterial extracts exhibit broad-spectrum or selective antibacterial activity? (3) Do different parts of the organism's body, particularly sponges, show the same antibacterial activity?

\section{Methods}

\section{Sample collection}

Samples were collected along several Antarctic expeditions. During the ANT XXI/2 cruise (November 2003 - January 2004) on board the RV Polarstern (Alfred Wegener Institute for Polar and Marine Research, Bremerhaven, Germany), benthic fauna were collected in the Eastern Weddell Sea and Bouvetøya (Bouvet Island) between $82.4 \mathrm{~m}$ and $1524.8 \mathrm{~m}$ depth using Bottom and Agassiz Trawls, Rauschert Dredge and Epibenthic Sledge (ECOQUIM cruise). During the ACTIQUIM-1 cruise (December 2008 - January 2009) benthic fauna and algae were collected from Deception, Livingston and Snow islands by scuba or intertidal sampling between $0.4 \mathrm{~m}$ and $17 \mathrm{~m}$ depth. In order to conduct a comprehensive study, 11 different phyla were selected. The main group was Porifera (38 taxa tested), followed by Cnidaria (16), Bryozoa (16), Echinodermata (14), Chordata (10), Mollusca (six), Annelida (four), Hemichordata (four), Nemertea (one) as well as two phyla of algae: Ochrophyta (four), and Rhodophyta (three).

\section{Chemical extractions}

Target organisms were carefully cleaned of epibiotic organisms. When possible, samples were dissected before chemical extraction to test the antibacterial activity of different parts of the body according to the optimal defense theory. A tissue portion from each sample was cut into small pieces $(\mathrm{ca} .1 \mathrm{~cm}$ ) and extracted by grinding and homogenizing in acetone with a mortar and pestle prior to exposure to ultrasonic waves for $10 \mathrm{~min}$. The acetonic extract was then sequentially partitioned into $100 \%$ diethyl ether $\left(\mathrm{Et}_{2} \mathrm{O}\right)$ and $100 \%$ butanol $(\mathrm{BuOH})$ extracts. A water residue was also obtained and kept for further studies. Fractionation steps were repeated three times, except for the butanol fraction, which was done twice. Organic solvents were evaporated in vacuo using a rotary evaporator. Diethyl ether (comprising the most apolar, lipophilic metabolites) and butanol (polar, hydrophilic metabolites) extracts were dissolved in a minimum volume of the extraction solvent and used for bioassays at natural concentrations. More details on the extraction procedure are reported elsewhere (Avila et al. 2000).

\section{Antarctic bacteria isolation}

Bacterial strains were isolated from shallow waters (up to $15 \mathrm{~m}$ depth), during four cruises at Deception Island in the South Shetland Islands (ACTIQUIM-1 in January - February 2009; ACTIQUIM-2 in January - February 2010; ACTIQUIM-3 in January - February 2012 and ACTIQUIM-4 in January - February 2013). Samples came from a stone (BAC-03), sediment (BAC-02), the sponge species Haliclona sp. Grant, 1836 (BAC-84), and three samples from seawater (BAC-75, BAC-76, BAC-77). Another strain (CSF) from the Mediterranean Sea was isolated from Cala Sant Francesc (Blanes, Catalonia, Spain) in May 2010.

For the cultures, $1 \mathrm{ml}$ aliquot of all samples was added to Difco ${ }^{\text {min }}$ marine broth 2216 (Difco Laboratories), left for $24-48 \mathrm{~h}$ at $20-37^{\circ} \mathrm{C}$, and subsequently cultured on Difco ${ }^{\text {tw }}$ marine agar plates. The resulting bacterial extracts were isolated, and the strain exhibiting the fastest growth was chosen for the assays. Details on isolation of these strains are described in Figuerola et al. (2014).

\section{Identification of bacterial isolates}

DNA from five out of seven bacterial strains was extracted using a Wizard ${ }^{\circledR}$ Genomic DNA Purification Kit (Promega) following the manufacturer's instructions. The $16 S$ rRNA gene was polymerase chain reaction amplified using universal primers $27 \mathrm{f}$ (5'AGAGTTTGATCMTGGCTCAG-3') and 1492r (5'TACGGYTACCTTGTTACGACTT-3') (Weisburg et al. 1991). For details on polymerase chain reaction conditions, sequencing and accession numbers for BAC-03, BAC-02 and BAC- 84 see Figuerola et al. (2014). The accession numbers for BAC-75 and CSF 
Table 1. Identification of bacterial isolates used in this study.

\begin{tabular}{|c|c|c|c|c|c|c|c|}
\hline Name & Identification & Cell wall & Origin & Source & Cruise & Month/year & Reference \\
\hline BAC-02 & Bacillus aquimaris & Gram + & Antarctic & Sediment & ACTIQUIM-3 & February/2012 & Figuerola et al. 2014 \\
\hline BAC-03 & Paracoccus sp. & Gram - & Antarctic & Rock & ACTIQUIM-4 & February/2013 & Figuerola et al. 2014 \\
\hline BAC-75 & Micrococcus sp. & Gram + & Antarctic & Seawater & ACTIQUIM-3 & February/2012 & This study \\
\hline BAC-76 & Unidentified & Unknown & Antarctic & Seawater & ACTIQUIM-1 & January/2009 & This study \\
\hline BAC-77 & Unidentified & Unknown & Antarctic & Seawater & ACTIQUIM-2 & January/2010 & This study \\
\hline BAC-84 & Oceanobacillus sp. & Gram + & Antarctic & Sponge & ACTIQUIM-3 & February/2012 & Figuerola et al. 2014 \\
\hline CSF & Corynebacterium sp. & Gram + & Mediterranean & Seawater & & May/2010 & This study \\
\hline
\end{tabular}

are KX267831 and KX279952, respectively. The remaining two bacterial strains, BAC-76 and BAC-77, could not be identified (Table 1).

\section{Antibacterial assay}

Antibacterial activity was tested using the disk diffusion method (Bhosale et al. 2002; Murugan \& Ramasamy 2003). To guarantee high bacterial densities, strains were grown in liquid medium $(99.4 \%$ seawater, $0.5 \%$ peptone, $0.1 \%$ yeast extract, $0.001 \%$ $\mathrm{FePO}_{4}$ ) at room temperature for at least three days prior to conducting the experiments. Inocula of $100 \mu \mathrm{l}$ of each strain were then spread on separate Zobell marine agar plates. Up to three extract disks (BBL paper disk infused with $20 \mu \mathrm{l}$ of extract resuspended in solvent), one neutral control (sterile paper disk), one negative control (paper disk with $20 \mu \mathrm{l}$ solvent only), and one positive control (chloramphenicol $30 \mu \mathrm{g} \mathrm{BD} \mathrm{BBL}{ }^{\mathrm{TM}} 230,733$ ) were placed onto the surface of each agar plate previously seeded with the individual bacterial strain. All solvents were evaporated before the test. Each assay was performed in triplicate for every extract on separate agar plates. All antibacterial assays were carried out with extracts at estimated natural concentrations in the organism (corrected by the biomass extracted) to test ecologically relevant dosages, as previously done and described by Figuerola et al. (2014).

Antibacterial activity was defined as a visible inhibition halo of cell growth in the region surrounding each paper disk. Inhibition zone categories followed those proposed by Mahon et al. (2003): (-) no effect, $0 \mathrm{~mm}$ zone; (+) weak growth inhibition zone, halo present but $<1 \mathrm{~mm}$ wide; $(++)$ medium growth inhibition, halo $\geq 1 \mathrm{~mm}$ and $\leq 2 \mathrm{~mm}$; (+++) strong growth inhibition, halo $>2 \mathrm{~mm}$ wide. The inhibition zones of the extracts were validated only when positive controls showed activity. No antibacterial activity was considered in extracts that caused a growth inhibition zone of 0.1-0.4 mm, as control solvent disk occasionally caused growth inhibition within this range. Therefore, estimates of microbial activity are conservative. Not all the extracts were tested against all the bacterial isolates due to material limitation. As these assays were blind experiments we tried to choose bacterial proxies from different environmental sources that were representative of genera associated with benthic invertebrates (Chelossi et al. 2004; Webster \& Bourne 2007; Heindl et al. 2012).

\section{Results}

A total of 255 samples that belonged to 116 taxa were used for the antibacterial assays (Supplementary Table S1). After separating different body parts, when possible, a total of 470 extracts were obtained (299 lipophilic and 171 hydrophilic extracts). These extracts were tested against seven strains of marine bacteria obtained as mentioned above. Over $20 \%$ of the lipophilic extracts from 38 taxa, mostly sponges, inhibited growth of at least one bacterial strain; less than $10 \%$ of the hydrophilic extracts from nine taxa did so at natural extract concentrations (Fig. 1). Seven out of those nine taxa also presented antibacterial activity in their lipophilic extracts. Thus, 40 taxa in total (34.5\%; Fig. 2) showed growth inhibition of at least one bacterial strain in their lipophilic and/or hydrophilic extracts. Regarding the antibacterial

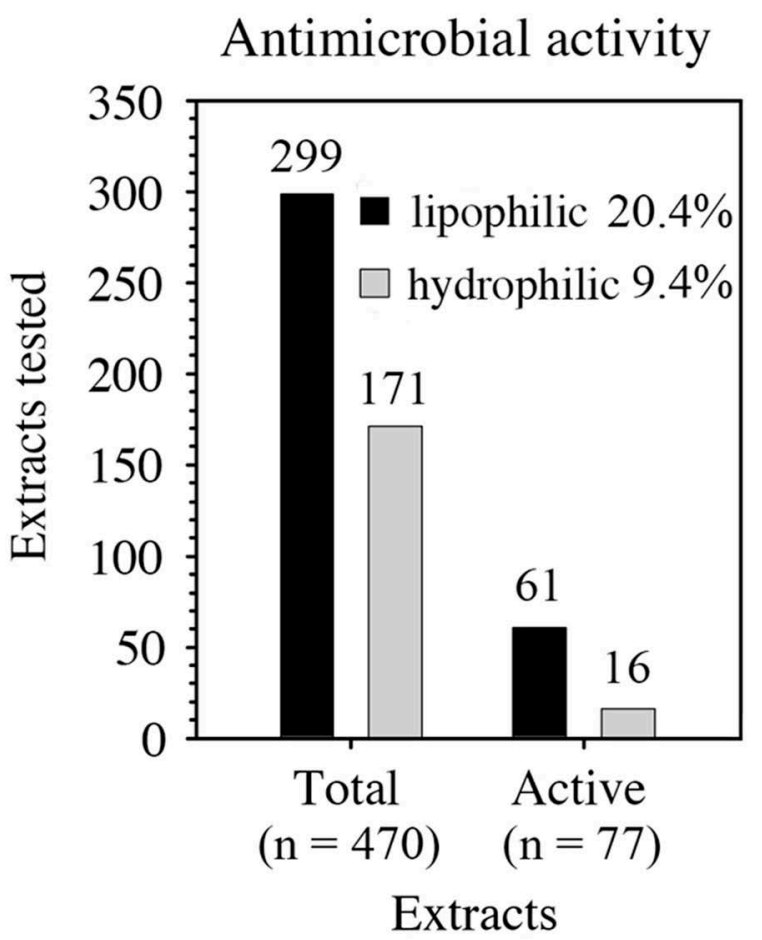

Figure 1. Antimicrobial activity of lipophilic (black) and hydrophilic (grey) extracts of Antarctic organisms tested. The number of extracts assayed is shown above each bar and the percentage of active extracts is shown beside each type of extract. 


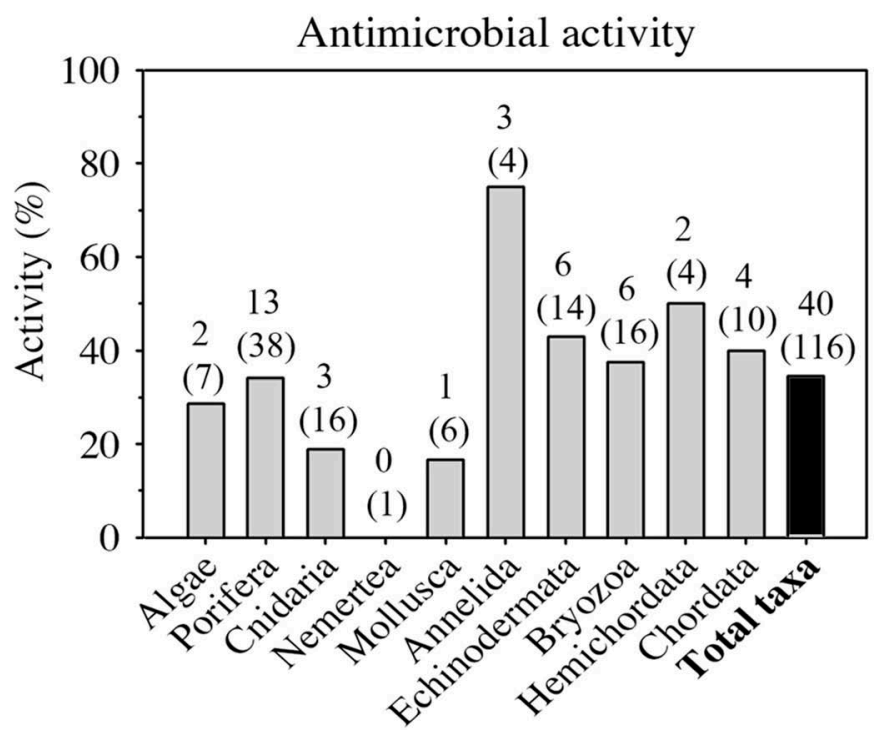

Figure 2. Percentage of antimicrobial activity of Antarctic organisms tested classified by phylum (except for algae, which merge two phyla). Above each bar the number of active taxa and the total taxa assayed (in parentheses) is shown.

activity by taxonomic group, Annelida presented the highest percentage of bacterial growth inhibition but only with four representatives. Around $40-50 \%$ of the taxa of Bryozoa (six out of 16), Echinodermata (six out of 14), Hemichordata (two out of four) and Chordata (four out of 10) showed antibacterial activity. Porifera, the most important group in terms of sampling effort (38 taxa), exhibited growth inhibition in $34 \%$ of its representatives sampled. Other groups such as Algae, Cnidaria and Mollusca showed antibacterial activity in $15-30 \%$ of its taxa. Finally, the single species of Nemertea tested presented no activity (Fig. 2).

Considering each bacterial strain separately, 17 lipophilic extracts were tested against Corynebacterium sp. (CSF) resulting in 12 positive tests (Table 2). Among the 96 lipophilic and hydrophilic extracts tested against Paracoccus sp. (BAC-03), only one lipophilic extract weakly inhibited the bacterial growth (Table 2). Ninety-nine lipophilic and 71 hydrophilic extracts were tested against Bacillus aquimaris (BAC-02). Almost 20\% of those lipophilic extracts (19) inhibited the growth of this strain, while only $8.5 \%$ of the hydrophilic extracts (six) showed a positive response (Table 2). We measured the inhibition activity of 17 lipophilic and 21 hydrophilic extracts against Micrococcus sp. (BAC-75) and just three and four extracts, respectively, inhibited the bacterial growth (Table 3). Three out of nine lipophilic extracts and six out of 21 hydrophilic extracts tested against Oceanobacillus sp. (BAC-84) presented inhibition responses (Table 3). The hydrophilic extracts seemed to have a greater inhibition effect on the last two bacteria tested. Two other unidentified bacteria were used in the antibacterial tests of 43 and 76 lipophilic extracts, respectively. Twenty-three percent of those extracts (10) inhibited growth of the bacterial strain BAC-76 and 18\% (14) showed growth inhibition of the strain BAC-77 (Table 3). All the details of the tests performed are summarized in Supplementary Tables S2-S8.

\section{Discussion}

Antarctic benthic organisms showed antibacterial activity against the marine bacterial strains tested in representatives of all phyla sampled, except for nemerteans, since we only tested a single taxon. Forty out of the 116 taxa tested $(34.5 \%)$ presented antibacterial activity against at least one bacterial strain and $90 \%$ of this activity produced strong inhibition ( $\geq 2 \mathrm{~mm}$ of halii inhibition zones). Just $21 \%$ of the active extracts (16 out of 77 ) showed inhibitory activity of multiple strains, suggesting that growth inhibition was quite selective. Thus, the presence of broad-spectrum antibacterial agents seems to be quite uncommon in Antarctic benthic organisms, at least as a general trend. Only a few invertebrates may possess the capability of producing compounds with widespectrum activity (Lippert et al. 2003). Although these inhibitory activities do not provide direct ecological evidence of the effects of naturally produced compounds in biological interactions, the positive crude extracts may contain potential antibacterial defenses but they need to be isolated and tested at a relevant ecological concentration. According to this, and given the low incidence of the positive responses, protection against marine bacteria does not seem to be a general mechanism established in Antarctic benthic organisms at least with this set of bacterial strains. However, those organisms with antibacterial activity strongly inhibit bacterial growth with inhibition halii 
Table 2. Inhibition of bacterial growth by the lipophilic extracts of Antarctic fauna tested.

\begin{tabular}{|c|c|c|c|c|}
\hline \multirow[b]{2}{*}{ Phyllum } & \multirow[b]{2}{*}{ Identification $^{\mathrm{a}}$} & \multirow{2}{*}{$\frac{\text { Corynebacterium sp. }(\mathrm{CSF})^{\mathrm{b}}}{\text { lipophilic }}$} & \multicolumn{2}{|c|}{ Paracoccus sp. $(\mathrm{BAC}-03)^{\mathrm{b}}$} \\
\hline & & & lipophilic & hydrophilic \\
\hline \multirow[t]{15}{*}{ Porifera } & Cinachyra barbata api ext & $0.7(0.5-1)+$ & & \\
\hline & Cinachyra barbata bas ext & $4.3(4-5)+++$ & & \\
\hline & Dendrilla antarctica int & & & \\
\hline & Iophon unicornis + Ophiurolepsis sp. (testing the ophiura's disc) & $0.7(0-2)+$ & & \\
\hline & Iophon unicornis + Ophiurolepsis sp. (testing the ophiura's arm) & $2(1-3)+++$ & & \\
\hline & Isodictya verrucosa api ext & & & \\
\hline & Mycale sp. int & & & \\
\hline & Mycale (Oxymycale) acerata & $1.5(0.5-2)++$ & & \\
\hline & Mycale (Oxymycale) acerata & & & \\
\hline & Mycale (Oxymycale) acerata & & & \\
\hline & Myxilla sp. & & & \\
\hline & Myxilla (Burtonanchora) magna & & & \\
\hline & Pyloderma latrunculoides int & & & \\
\hline & Rossella sp. ext & & & \\
\hline & Stylocordyla chupachups api & & & \\
\hline \multirow[t]{2}{*}{ Cnidaria } & Primnoisis antarctica & $1.5(0.5-2)++$ & & \\
\hline & Primnoisis antarctica & & & \\
\hline \multirow[t]{2}{*}{ Mollusca } & Limopsis marionensis int & & & \\
\hline & Limopsis marionensis ext & & & \\
\hline \multirow[t]{2}{*}{ Annelida (Polychaeta) } & Aglaophamus cf. trissophyllus & $3.7(3-5)+++$ & & \\
\hline & Pista spinifera & & & \\
\hline \multirow[t]{5}{*}{ Bryozoa } & Camptoplites tricornis & & & \\
\hline & Camptoplites bicornis & & & \\
\hline & Klugella echinata & & & \\
\hline & Nematoflustra flagellata & & $0.5(0.5-0.5)+$ & - \\
\hline & Systenopora contracta & $1.7(1-3)++$ & & \\
\hline \multirow[t]{4}{*}{ Echinodermata } & Acodontaster hodgsoni int & & & \\
\hline & Ophionotus victoriae disc & & & \\
\hline & orange ophiuroid (unidentified) & & & \\
\hline & Peniagone vignioni & $1.3(1-2)++$ & & \\
\hline \multirow[t]{2}{*}{ Hemichordata } & Cephalodiscus cf. nigrescens & & & \\
\hline & Cephalodiscus sp. & $1.7(1-3)++$ & & \\
\hline \multirow[t]{2}{*}{ Chordata } & Aplidium falklandicum & $2.7(1-4)+++$ & & \\
\hline & Aplidium meridianum & $1.7(1-2)++$ & & \\
\hline
\end{tabular}

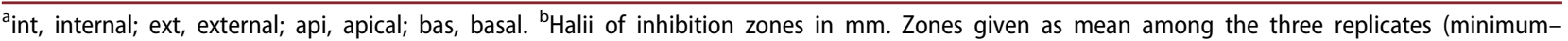
maximum value). Antimicrobial activity against bacterial strains classified after Mahon et al. (2003): - no effect, + weak growth inhibition, ++ medium growth inhibition, +++ strong growth inhibition. Blank not tested. These categories have to be considered with caution since the diffusion rate of some antimicrobial compounds could perhaps also affect the size of the halii (Martín-Rodríguez et al. 2014).

ranging from 7 to $14 \mathrm{~mm}$. Although the release of bioactive compounds into the seawater or the surface availability of these metabolites to biofilm-forming bacteria have not been investigated in this study, many reports have documented these allelochemical paths to prevent predation, competition or fouling (e.g., Kubanek et al. 2002; Richelle-Maurer et al. 2003; Paul et al. 2011).

Of the bacterial strains used in this study, all were inhibited by multiple Antarctic benthic organisms. However, only one extract caused weak inhibition of Paracoccus sp. (BAC-03). This gram-negative bacterium was observed to be resistant to antimicrobial agents of bryozoans (Figuerola et al. 2014) but also of other benthic organisms (this study). Antibacterial responses of crude organic extracts were higher to gram-positive bacteria. Nonetheless, only one gramnegative bacterium was tested. Between $18-30 \%$ of the extracts showed inhibitory responses against most of the isolates. Thus, Antarctic benthic organisms seemed to be equally defended against marine bacteria irrespective of the isolation source (i.e., rock/ sediment, sponge, seawater), except for the Mediterranean strain (CSF), from shallow waters, which was inhibited in 12 out of 17 assays. Assessing the antibacterial activity against a Mediterranean microorganism can be helpful to evaluate the potential usefulness of natural products in the discovery of new antimicrobials. Isolating the compounds responsible for that activity would be of value in ecology because it may imply the presence of antibacterials with a broad spectrum of effectiveness against marine bacteria that may prevent fouling or over-growth by marine organisms.

Unlike the extensive body of work published on chemical feeding-deterrent interactions of Antarctic marine benthic invertebrates, there is very limited information about potential antimicrobial agents. Among all phyla tested in this study, Annelida presented the highest percentage of bacterial inhibition effect but with only four representatives, three of which were active. The production of natural compounds with antimicrobial properties by annelids is well known at different geographic latitudes but not in the Antarctic region (Chain \& Anderson 1983; Elayaraja et al. 2010; Maltseva et al. 2014). Bryozoa, Echinodermata, Hemichordata and Chordata were better sampled, with a percentage of active organisms 


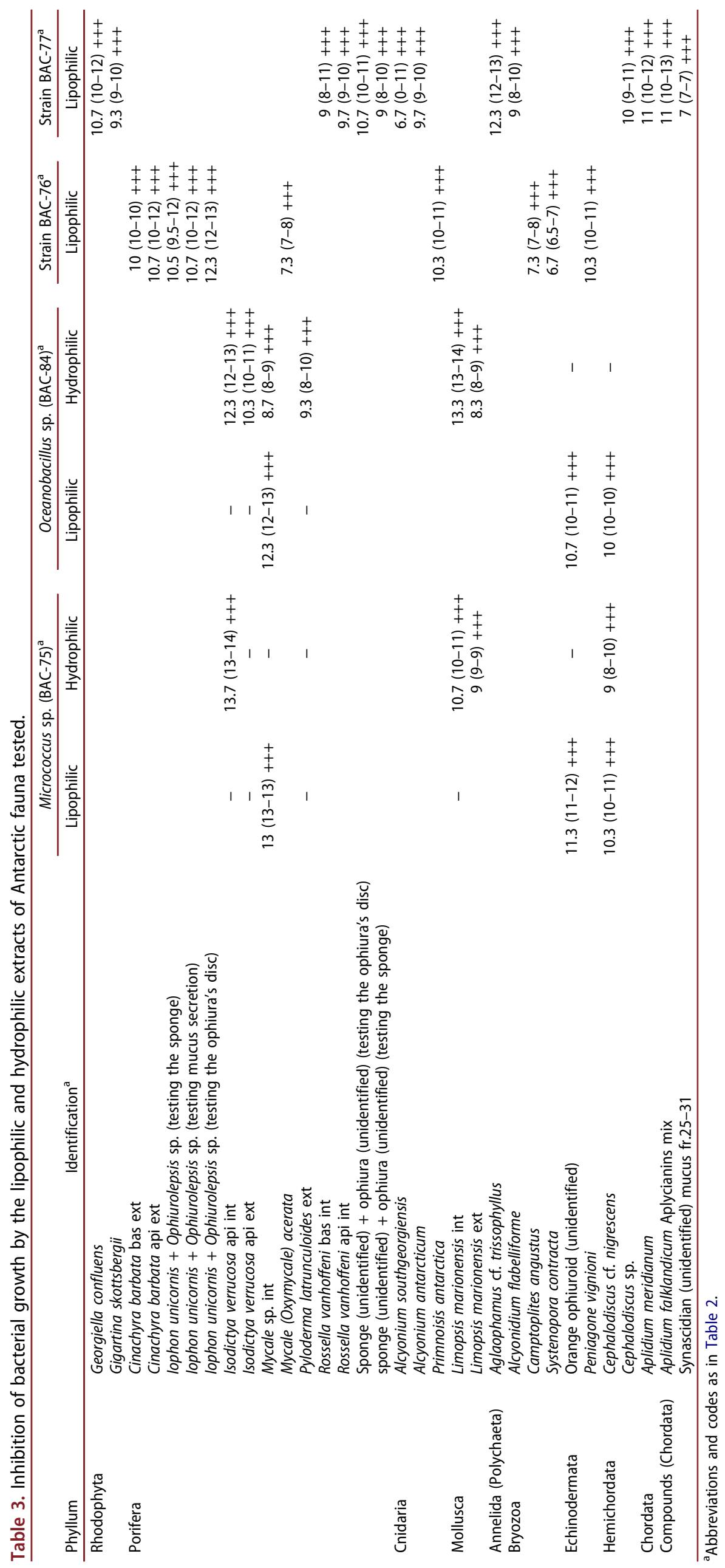


of $40-50 \%$. The antimicrobial and antifouling activities of bryozoans and tunicates in the Southern Ocean are also better studied (Koplovitz et al. 2011; Figuerola et al. 2014). This is not the case with echinoderms; though considered key macroinvertebrate predators in Antarctic benthic ecosystems (Dearborn et al. 1983; Dearborn \& Edwards 1984), their potential antimicrobial interactions are scarcely known. Phylum Hemichordata is even more poorly represented in the literature on Antarctic chemical ecology, being almost absent. Other groups such as Algae, Cnidaria and Mollusca showed antibacterial activity in $15-30 \%$ of their taxa tested in this study. The presence of antimicrobials in some species of soft corals and sea fans is already known (Slattery et al. 1995; Angulo-Preckler, Spurkland et al. 2015). However, there is a gap in the prospective role of compounds with inhibitory properties in gastropods, bivalves and other molluscs. Research on Antarctic macroalgae chemical ecology, though, has mainly been focused on chemical defenses against herbivores, and also on diatom fouling (Amsler \& Fairhead 2005; Amsler et al. 2005). So far, Porifera shows the best-documented group of chemically mediated interactions in Antarctica, including antimicrobial and antifouling activities (Avila et al. 2008). Sponges are the dominant macroinvertebrate organisms in many Antarctic benthic communities (Dayton et al. 1974), and are the most sampled phyla of our study (38 taxa). They exhibited growth inhibition in $34 \%$ of its representatives. Nonetheless, antibacterial properties of sponge extracts seem to be sponge-specific, causing diverse inhibition responses (McClintock \& Gauthier 1992; Turk et al. 2013).

The active taxa of this study showed antibacterial activity in its lipophilic and/or hydrophilic crude extracts, although the percentage was larger with lipophilic compounds. However, other studies found either mild or no inhibitory activity of hydrophilic extracts against marine bacteria from polar regions (Peters et al. 2010; Turk et al. 2013; Angulo-Preckler, Spurkland et al. 2015). Potential lipophilic and hydrophilic bioactive compounds of the same taxa can show antibacterial activities such as the sponge Mycale sp. and the mollusc Limopsis marionensis against Oceanobacillus sp. and Bacillus aquimaris, respectively. Perhaps some amphiphilic compounds are behind this bioactivity. Besides chemical protection against diatom fouling (Amsler et al. 2000; Peters et al. 2010), Antarctic invertebrates appear to be protected against bacterial growth with certain specificity of the inhibitory properties. The fouling process follows a series of successional stages. Initially attached microorganisms can attract macro-foulers (e.g., diatoms) that can allow the settlement of other organisms (e.g., larvae) (Wahl 1989). Hence, colonization of macro-foulers can attract micro- and macro-predators (Lippert et al. 2003). Although antifouling mechanisms need to be further investigated by testing isolated compounds with potential bioactivity, they do not seem to be a major driving force in structuring Antarctic benthic communities (Gutt \& Starmans 1998; Gutt 2000). There might be other driving forces, either physical factors such as iceberg scouring (Gutt 2000), or other biological interactions, such as predation or commensalism (Gutt \& Starmans 1998), that structure Antarctic benthic communities, explaining patterns of distribution and dispersion. Whether another selective pressure such as predation, apparently greater, has an indirect effect, according to the fouling process, on the presence of antimicrobial compounds in several benthic organisms (Slattery et al. 1995; Peters et al. 2010) is largely unknown.

Among the organisms tested in this study, sponges were the group with most active taxa. We found differences in the antibacterial activity of different body parts. Since the allocation of chemical defenses may vary as predicted by the optimal defense theory outlined by McKey (1979) and Rhoades (1979) in plants and reviewed by Cronin (2001), we can also assess differences in the antimicrobial activity of different body parts according to the vulnerability of these parts to be attacked. Optimal defense theory assumes that the resources for the production of natural products are limited and predicts that chemical defenses should be allocated to those tissues most vulnerable or most likely to maximize fitness. Some sponge species (e.g., Latrunculia brevis, Anoxycalyx [Scolymastra] joubini) showed no inhibitory activity against the panel of marine bacteria tested, most likely because these bacterial strains had no harmful effect on them. However, we found differential antibacterial activity between external and internal layers of other sponges. The outer parts of Cinachyra barbata and Rossella sp. seemed to be better protected than inner parts. Conversely, the inner cores of Mycale sp. and Rossella vanhoffeni were more protected than surface layers. Other sponges such as Isodictya verrucosa and Pyloderma latrunculoides presented activity in both external and internal regions depending on the bacterial strain tested. Concerning predation, the allocation of defensive compounds in the surface of the organism may offer more effective protection against sea star spongivory (Furrow et al. 2003). However, protection of outer and inner layers against infections or fouling may be equally efficient as microbes can encounter both external and internal cells during sponge water pumping. Thus, optimal defense theory predictions that were expected to apply to antimicrobial or antifouling defenses in this case may not do so (Angulo-Preckler, Cid et al. 2015).

We found a particular case in which different brittle stars were covered with a sponge and we tested 
both organisms separately. The data we obtained from these assays did not lead to conclusive results. In some tests the sponges caused the inhibition of a particular bacterial strain but in other tests did not, and the brittle stars assays led to similar results. The idea of synergies in the antibacterial activity of these associated benthic organisms, or whether an organism benefits from the chemical protection of another, should be further investigated.

Some variability was also detected in the inhibitory activity between individuals of the same species and among species of the same genus. The lipophilic extracts of the bryozoan Camptoplites angustus and the tunicate Aplidium meridianum and the hydrophilic extract of the cnidarian Primnoisis antarctica showed differential antibacterial activity against the strains BAC-76, BAC-03 (Paracoccus sp.) and BAC02 (Bacillus aquimaris), respectively. At an interspecific level, sponges of the genus Rossella and cnidarians of the genus Alcyonium exhibited distinct inhibition growth of the bacterium Paracoccus sp. This pattern of variation might be explained by the inducible defense model (Karban \& Myers 1989; Harvell 1990). The inducible defense model predicts that defenses should be produced constitutively if risk of attack is always high, not produced ever if always low, and produced only when an organism is under attack or fouling (i.e., induced) if offense pressure is variable in space and/or time and if attack occurs slowly enough for a defense to be produced in time to be effective. Without knowing the occurrence of microbial encounters with individual benthic organisms we can only speculate about the possibility of differential fouling levels resulting in differential inhibitory activities. However, the high diversity of bacterioplankton in mesopelagic Antarctic waters and its local variability (Yu et al. 2015) are likely to favour the evolution of induced defenses on potentially fouled Antarctic benthos (Amsler 2001). These contrasting patterns may also be explained by different concentrations of natural products or by diverse natural compounds causing different grades of inhibition.

\section{Conclusion}

Most of the literature on Antarctic chemical ecology is focused on predator/deterrent interactions of a reduced number of phyla and the prospective roles of natural products on antimicrobial activities remain mostly unknown, thus providing a potential source of interesting bioactive natural products from Antarctic benthic communities. Our research showed that potential antibacterial defenses are present in a number of different organism phyla in Antarctica. However, inhibitory activity is quite selective and species-specific. Different intra/interspecific patterns of antibacterial activity were found, suggesting that Antarctic benthic organisms may produce diverse bioactive metabolites with different active concentrations or those contrasting chemical profiles may be shaped by environmental conditions or biological interactions (i.e., selective pressures) acting at a spatial micro-scale. Although these hypotheses remain to be ecologically tested, the role of symbionts, perhaps other microorganisms, in this bioactivity also deserves further analyses. This study is a first step towards the screening of potential novel marine compounds focusing on specific taxa presenting inhibitory properties. Developing new studies of antimicrobial activity against sympatric microorganisms jointly with determining which compounds are responsible for that activity will help us to understand the ecological role that natural products play in nature and the potential regulation of chemical defense production.

\section{Acknowledgements}

In this work we used the extracts from previous ECOQUIM projects; for this reason we want to thank W. Arntz, and the RV Polarstern and the BIO-Hesperides crews. We would like to thank as well the Unidad de Tecnología Marina and the crew of the Las Palmas vessel for all their logistic support. Special thanks are also given to the BAE Gabriel de Castilla crew for their help. Thanks are due to A. Gómez-Garreta, J. Rull, B. Figuerola, J. Moles, L. Núñez-Pons, P. Ríos, J. Cristobo and S. Taboada, for their help with some taxonomic identifications. C. García-Aljaro and E. Juan i Ardanuy provided help with bacterial identification. We also thank the anonymous reviewers for their valuable remarks. At the time of the research reported here, OSS was at the Department of Evolutionary Biology, Ecology and Environmental Sciences, Biodiversity Research Institute, Faculty of Biology, University of Barcelona.

\section{Disclosure statement}

No potential conflict of interest was reported by the authors.

\section{Funding}

This research was developed in the framework of the ACTIQUIM I and II projects (CGL2007-65453/ANT, CTM2010-17415/ANT) with the financial support of the Spanish Government.

\section{ORCID}

Oriol Sacristán-Soriano 4900-884X

Carlos Angulo-Preckler (D) http://orcid.org/0000-00019028-274X

Conxita Avila (D) http://orcid.org/0000-0002-5489-8376 


\section{References}

Amsler C.D. 2001. Induced defenses in macroalgae: the herbivore makes a difference. Journal of Phycology 37, 353-356.

Amsler C.D. \& Fairhead V.A. 2005. Defensive and sensory chemical ecology of brown algae. In J. Callow (ed.): Advances in botanical research. Vol. 43. Pp. 1-91. London: Academic Press.

Amsler C.D., Moeller C., McClintock J.B., Iken K. \& Baker B.J. 2000. Chemical defenses against diatom fouling in Antarctic marine sponges. Biofouling 16, 29-45.

Amsler C.D., Okogbue I.N., Landry D.M., Amsler M.O., McClintock J.B. \& Baker B.J. 2005. Potential chemical defenses against diatom fouling in Antarctic macroalgae. Botanica Marina 48, 318-322.

Angulo-Preckler C., Cid C., Oliva F. \& Avila C. 2015. Antifouling activity in some benthic Antarctic invertebrates by in situ experiments at Deception Island, Antarctica. Marine Environmental Research 105, 30-38.

Angulo-Preckler C., Spurkland T., Avila C. \& Iken K. 2015. Antimicrobial activity of selected benthic Arctic invertebrates. Polar Biology 38, 1941-1948.

Arntz W.E., Thatje S., Gerdes D., Gili J.M., Gutt J., Jacob U., Montiel A., Orejas C. \& Teixidó N. 2005. The Antarctic-Magellan connection: macrobenthos ecology on the shelf and upper slope, a progress report. Scientia Marina 69, 237-269.

Avila C., Iken K., Fontana A. \& Cimino G. 2000. Chemical ecology of the Antarctic nudibranch Bathydoris hodgsoni Eliot, 1907: defensive role and origin of its natural products. Journal of Experimental Marine Biology and Ecology 252, 27-44.

Avila C., Taboada S. \& Núñez-Pons L. 2008. Antarctic marine chemical ecology: what is next? Marine Ecology 29, 1-71.

Bhosale S.H., Nagle V.L. \& Jagtap T.G. 2002. Antifouling potential of some marine organisms from India against species of Bacillus and. Pseudomonas. Marine Biotechnology 4, 111-118.

Chain B.M. \& Anderson R.S. 1983. Antibacterial activity of the coelomic fluid of the polychaete, Glycera dibranchiata. I. The kinetics of the bactericidal reaction. The Biological Bulletin 164, 28-40.

Chelossi E., Milanese M., Milano A., Pronzato R. \& Riccardi G. 2004. Characterisation and antimicrobial activity of epibiotic bacteria from Petrosia ficiformis (Porifera, Demospongiae). Journal of Experimental Marine Biology and Ecology 309, 21-33.

Cronin G. 2001. Resource allocation in seaweeds and marine invertebrates: chemical defense patterns in relation to defense theories. In J.B. McClintock \& B.J. Baker (eds.): Marine chemical ecology. Pp. 325-353. Boca Raton, FL: CRC Press.

Dayton P.K., Robilliard G.A., Paine R.T. \& Dayton L.B. 1974. Biological accommodation in the benthic community at McMurdo Sound, Antarctica. Ecological Monographs 44, 105-128.

Dearborn J.H. \& Edwards K.C. 1984. Analysis of data on the feeding biology of Antarctic sea stars and brittle stars. Antarctic Journal of the USA 19, 138-139.

Dearborn J.H., Edwards K.C., Fratt D.B. \& Zamer W.E. 1983. Echinoderm studies along the Antarctic Peninsula. Antarctic Journal of the USA 18, 193-194.

Elayaraja S., Murugesan P., Vijayalakshmi S. \& Balasubramanian T. 2010. Antibacterial and antifungal activities of polychaete Perinereis cultrifera. Indian Journal of Marine Sciences 39, 257-261.

Figuerola B., Sala-Comorera L., Angulo-Preckler C., Vázquez J., Jesús Montes M., García-Aljaro C., Mercadé E., Blanch A.R. \& Avila C. 2014. Antimicrobial activity of Antarctic bryozoans: an ecological perspective with potential for clinical applications. Marine Environmental Research 101, 52-59.

Furrow F.B., Amsler C.D., McClintock J.B. \& Baker B.J. 2003. Surface sequestration of chemical feeding deterrents in the Antarctic sponge Latrunculia apicalis as an optimal defense against sea star spongivory. Marine Biology 143, 443-449.

Gutt J. 2000. Some "driving forces" structuring communities of the sublittoral Antarctic macrobenthos. Antarctic Science 2, 297-313.

Gutt J. \& Starmans A. 1998. Structure and biodiversity of megabenthos in the Weddell and Lazarev seas (Antarctica): ecological role of physical parameters and biological interactions. Polar Biology 20, 229-247.

Harder T., Lau S.C.K., Dobretsov S., Fang T. \& Qian P.Y. 2003. A distinctive epibiotic bacterial community on the soft coral Dendronephthya sp. and antibacterial activity of coral tissue extracts suggest a chemical mechanism against bacterial epibiosis. FEMS Microbiology Ecology 43, 337-347.

Harvell C.D. 1990. The ecology and evolution of inducible defenses. The Quarterly Review of Biology 65, 323-340.

Heindl H., Thiel V., Wiese J. \& Imhoff J.F. 2012. Bacterial isolates from the bryozoan Membranipora membranacea: influence of culture media on isolation and antimicrobial activity. International Microbiology 15, 17-32.

Jenkins K., Jensen P.R. \& Fenical W. 1998. Bioassays with marine microorganisms. Methods in chemical ecology. In K. Haynes \& J. Millar (eds.): Bioassay methods. New York: Chapman and Hall.

Karban R. \& Myers J.H. 1989. Induced plant-responses to herbivory. Annual Review of Ecology and Systematics 20, 331-348.

Koplovitz G., McClintock J.B., Amsler C.D. \& Baker B.J. 2011. A comprehensive evaluation of the potential chemical defenses of Antarctic ascidians against sympatric fouling microorganisms. Marine Biology 158, 2661-2671.

Kubanek J., Whalen K.E., Engel S., Kelly S.R., Henkel T.P., Fenical W. \& Pawlik J.R. 2002. Multiple defensive roles for triterpene glycosides from two Caribbean sponges. Oecologia 131, 125-136.

Lebar M.D., Heimbegner J.L. \& Baker B.J. 2007. Cold-water marine natural products. Natural Product Reports 24, 774-797.

Lippert H., Brinkmeyer R., Mulhaupt T. \& Iken K. 2003. Antimicrobial activity in sub-Arctic marine invertebrates. Polar Biology 26, 591-600.

Mahon A.R., Amsler C.D., McClintock J.B., Amsler M.O. \& Baker B.J. 2003. Tissue-specific palatability and chemical defenses against macropredators and pathogens in the common articulate brachiopod Liothyrella uva from the Antarctic Peninsula. Journal of Experimental Marine Biology and Ecology 290, 197-210.

Maltseva A.L., Kotenko O.N., Kokryakov V.N., Starunov V. V. \& Krasnodembskaya A.D. 2014. Expression pattern of arenicins-the antimicrobial peptides of polychaete Arenicola marina. Frontiers in Physiology 5, article no. UNSP 497, doi: 10.3389/fphys.2014.00497

Martín-Rodríguez A.J., González-Orive A., HernándezCreus A., Morales A., Dorta-Guerra R., Norte M., Martín V.S. \& Fernández J.J. 2014. On the influence of 
the culture conditions in bacterial antifouling bioassays and biofilm properties: Shewanella algae, a case study. BMC Microbiology 14, 102.

McClintock J.B. \& Gauthier J.J. 1992. Antimicrobial activities of Antarctic sponges. Antarctic Science 4, 179-183.

McKey D. 1979. The distribution of secondary compounds within plants. In G.A. Rosenthal \& G.H. Janzen (eds.): Herbivores: their interaction with secondary plant metabolites. Pp. 55-133. New York: Academic Press.

Meyer B. \& Kuever J. 2008. Phylogenetic diversity and spatial distribution of the microbial community associated with the Caribbean deep-water sponge Polymastia cf. corticata by $16 \mathrm{~S}$ rRNA, aprA, and amoA gene analysis. Microbial Ecology 56, 306-321.

Murugan A. \& Ramasamy M. 2003. Biofouling deterrent activity of the natural product from ascidian, Distaplia nathensis (Chordata). Indian Journal of Marine Science 32, 162-164.

Núñez-Pons L., Forestieri R., Nieto R.M., Varela M., Nappo M., Rodríguez J., Jiménez C., Castelluccio F., Carbone M., Ramos-Espla A., Gavagnin M. \& Avila C. 2010. Chemical defenses of tunicates of the genus Aplidium from the Weddell Sea (Antarctica). Polar Biology 33, 1319-1329.

Núñez-Pons L., Rodríguez-Arias M., Gómez-Garreta A., Ribera-Siguán A. \& Avila C. 2012. Feeding deterrency in Antarctic marine organisms: bioassays with the omnivore amphipod Cheirimedon femoratus. Marine Ecology Progress Series 462, 163-174.

Papaleo M.C., Fondi M., Maida I., Perrin E., Lo Giudice A., Michaud L., Mangano S., Bartolucci G., Romoli R. \& Fani R. 2012. Sponge-associated microbial Antarctic communities exhibiting antimicrobial activity against Burkholderia cepacia complex bacteria. Biotechnology 30, 272-293.

Paul V.J., Ritson-Williams R. \& Sharp K. 2011. Marine chemical ecology in benthic environments. Natural Product Reports 28, 345-387.

Peters K.J., Amsler C.D., McClintock J.B. \& Baker B.J. 2010. Potential chemical defenses of Antarctic sponges against sympatric microorganisms. Polar Biology 33, 649-658.

Peters K.J., Amsler C.D., McClintock J.B., Van Soest R.W. M. \& Baker B.J. 2009. Palatability and chemical defenses of sponges from the western Antarctic Peninsula. Marine Ecology Progress Series 385, 77-85.

Piel J. 2004. Metabolites from symbiotic bacteria. Natural Product Reports 21, 519-538.

Piel J. 2009. Metabolites from symbiotic bacteria. Natural Product Reports 26, 338-362.
Rhoades D.F. 1979. Evolution of plant chemical defense against herbivores. In G.A. Rosenthal \& G.H. Janzen (eds.): Herbivores: their interaction with secondary plant metabolites. Pp. 1-55. New York: Academic Press.

Richelle-Maurer E., De Kluijver M.J., Feio S., Gaudêncio S., Gaspar H., Gomez R., Tavares R., Van De Vyver G. \& Van Soest R.W.M. 2003. Localization and ecological significance of oroidin and sceptrin in the Caribbean sponge Agelas conifera. Biochemical Systematics and Ecology 31, 1073-1091.

Slattery M., McClintock J.B. \& Heine J.N. 1995. Chemical defenses in Antarctic soft corals: evidence for antifouling compounds. Journal of Experimental Marine Biology and Ecology 190, 61-77.

Thiel V., Neulinger S.C., Staufenberger T., Schmaljohann R. \& Imhoff J.F. 2007. Spatial distribution of spongeassociated bacteria in the Mediterranean sponge Tethya aurantium. FEMS Microbiology Ecology 59, 47-63.

Turk T., Ambrožič Avguštin J., Batista U., Strugar G., Kosmina R., Čivović S., Janussen D., Kauferstein S., Mebs D. \& Sepčić K. 2013. Biological activities of ethanolic extracts from deep-sea Antarctic marine sponges. Marine Drugs 11, 1126-1139.

Wahl M. 1989. Marine epibiosis. I. Fouling and antifouling: some basic aspects. Marine Ecology Progress Series 58, 175-189.

Walls J.T., Ritz D.A. \& Blackman A.J. 1993. Fouling, surface bacteria and antibacterial agents of four bryozoan species found in Tasmania, Australia. Journal of Experimental Marine Biology and Ecology 169, 1-13.

Webster N.S. \& Bourne D. 2007. Bacterial community structure associated with the Antarctic soft coral, Alcyonium antarcticum. FEMS Microbiology Ecology 59, 81-94.

Weisburg W.G., Barns S.M., Pelletier D.A. \& Lane D.J. 1991. 16S ribosomal DNA amplification for phylogenetic study. Journal of Bacteriology 173, 697-703.

Wiencke C., Clayton M., Gómez I., Iken K., Lüder U.H., Amsler C.D., Karsten U., Hanelt D., Bischof K. \& Dunton K. 2007. Life strategy, ecophysiology and ecology of seaweeds in polar waters. Reviews in Environmental Science and Biotechnology 6, 95-126.

Xin Y., Kanagasabhapathy M., Janussen D., Xue S. \& Zhang W. 2011. Phylogenetic diversity of Gram-positive bacteria cultured from Antarctic deep-sea sponges. Polar Biology 34, 1501-1512.

Yu Z., Yang J., Liu L., Zhang W. \& Amalfitano S. 2015. Bacterioplankton community shifts associated with epipelagic and mesopelagic waters in the Southern Ocean. Scientific Reports 5, article no. 12897, doi: 10.1038/ srep 12897 